\title{
THE SUMMARY POWER TO PUNISH FOR CONTEMPT
}

In the past three quarters of a century there have been many signs that the power to punish summarily for contempt of court is encroaching upon the once sacred "right" of trial by jury in criminal cases:- e.g., summary punishments for crimes affecting receiverships; ${ }^{1}$ the labor injunction, which, though it is a main subject of my interest, will receive only casual further mention here; various other instances where, in form, the question is rather as to scope of chancery power to enjoin than as to the scope of the contempt power $;^{1 a}$ and finally a small but growing class of cases, of which the Sinclair case, ${ }^{2}$ discussed later in this article, is an extreme instance, in which the question of summary punishment for crime is unconfused with that of equity jurisdiction. Trial by jury was an important egg in the setting from which democracy was hatched. And its decline is cumulative of much other evidence that democracy itself is in decline. That may be neither preventible nor evil; the place for what is worn out is the scrap-heap. It is possible that values that were well served by democracy and the jury system in their prime may now be served better otherwise. But the devious and obscure processes of social change involve danger that real values may be sacrificed without our knowing it. Unsatisfactory though trial by jury has become, it does not follow that trial by a judge who is not directly checked by unprofessional common sense and common feeling is necessarily better. Answer to the question of how criminal justice may become efficient involves vastly more than easy choice between those two alternatives. For satisfactory answer, that question must be clearly faced. This paper is motived by a hope of contributing indirectly to that end, by stamping for what it is one of the red herrings-the punitive use of the contempt powerwhich confuse the scent of the true question. A view of the reason-

${ }^{1}$ Which I have lately considered in an appendix to $A$ Strike and Its Legal Consequences-An Examination of the Receivership Precedent for the Labor Injunction (1931) 40 YaLe L. J. 507, 534 et seq.

${ }_{13}$ To a consideration of that question this paper is preliminary. Since it went to press I have had the privilege of reading in manuscript an interesting article by Professor Harmon Caldwell, to appear in the Ilcivors LAW REviEw during the fall of 1931, on Injunctions to Prevent Crime.

"The Minnesota statute authorizing injunctive prohibition of the publication of defamatory newspapers was held unconstitutional by the Supreme Court of the United States in Near v. State of Minnesota, U. S. Daily June 2, 1931, reversing State v. Guilford, infra note 36."

${ }^{2}$ Sinclair v. United States, 279 U. S. 749, 49 Sup. Ct. 471 (1929). 
able scope of the contempt power which is orthodox, at least in the abstract, is presented, and judicial inconsistencies therewith are deplored. For encroachments upon jury tria ${ }^{3}$ by perversion of the contempt power tend rather to evasion than solution of the problem of efficient criminal justice.

\section{The Theory of the Summary Power}

Criminal proceedings, said Blackstone, "are divisible into two kinds: summary and regular." The institution of summary proceedings is principally legislative; "for the common law is a stranger to it, unless in the case of contempts." In other cases he found that it had "of late been so far extended, as if a check be not timely given, to threaten the disuse of our admirable and truly English trial by jury"; the danger of arbitrary power outweighed, he thought, the benefit of speedy but erratic justice. The summary and inquisitorial procedure for contempt, however, though "not agreeable to the genius of the common law in any other instance," seemed to him to result "from the first principles of judicial establishments." And he concluded (incorrectly, as modern scholarship has shown) that it had been used immemorially and was confirmed by Magna Carta as part of the law of the land. ${ }^{4}$

Whatever the date and legitimacy of its birth, the summary procedure for contempt is an old exception to the principle that trial by jury is essential to due process of law. Since the exception is in derogation of the principle, it would be natural to find its limits both closely and clearly defined. The contrary, however, is the case. "Contempt of court (which has been irreverently termed a 'legal thumb-screw') is so manifold in its aspects that it is difficult to lay down any exact definition of the offense." The most autocratic of judicial powers is likewise in practice the most indefinite.

Its vagueness is accounted for by the fact that the law of contempt, unlike our judge-made law in general, develops in large measure (1) in cases where exasperation tends to cloud judgment, and (2) in cases which are virtually $e x$ parte. Rules declared in great cases of the first class have frequently, though untraceably, started in petty cases of the second. In petty cases the alleged contemnor is ordinarily gnilty of some misconduct. He has no great stake in establishing that his misconduct is not technically contempt, or punishable summarily. His

${ }^{3}$ Dean Wigmore in A Program for the Trial of Jury Trial (1929) $12 \mathrm{~J}$. AM. Jud. Soc. 166, suggests that most of the faults of jury trial as we now have it are remediable.

4 BL. Concm. 280-8. For contrary conclusions based upon historical evidence instead of assumption, see SIR JoH N Fox, ConTEMPT of Court (1927).

${ }^{5}$ Oswald, Contenipt of Court (3d ed. 1911) 5. 
safest and most economical course, even if his conduct was in truth rightful, is to placate wrath by apology and submission. For should he assert either a substantive right to his behavior or an adjective right to ordinary criminal procedure, he faces these probabilities: that his contention will be overruled; that his obstreperousness will spoil his chance to escape with a reprimand or a nominal fine; that the expense of an appeal will be prohibitive. ${ }^{6}$ If his offense is gross, moreover, his success in maintaining that it is not summarily punishable may result only in his exposure to more substantial expense, punishment and stigmatization in a prosecution by indictment. Unless, as rarely happens except in cases of contempt by publication, he is concerned to vindicate a principle, the game of litigious disputation will usually seem not to be worth the candle. Neither issues of principle nor enormities of conduct conduce to judicial detachment. It is natural, therefore, that the "process of inclusion and exclusion," however it may have clarified the law of other subjects, has had a contrary tendency in the law of contempt. The limits of principles and precedents are rarely subjected to searching examination. The authority of sweeping dicta is rarely successfully challenged. And facile reliance upon superficial analogies also contributes to extensions of the summary power which are at variance with the principles upon which it relies for justification.

What are those principles?

The amplitude of the crime of contempt-not, however, the amplitude of the summary power-dates from antiquity. The writ of attachment for contempt still, in England, describes the contempt, not as against the court, but as against the King. Originally, probably, whatever was lèse majesté was contempt, and the range was all the way from treason to a breach of decorum. ${ }^{7}$ The administration of justice was protected not merely because it was the administration of justice but because the judges were vice-roys; they "sit in the Seat of King concerning his Justice."s Even today the feeling that injured judicial majesty is per se entitled to vindication through punishment for con-

- In England indeed findings of so-called criminal contempt are still not appealable. Ibid. 229. Their general (not yet universal) appealability in this country is rather recent. See, e.g., Bessette v. Conkey Co., 194 U. S. 324, 24 Sup. Ct. 665 (1904). The long effort to use habeas corpus as a substitute for appeal in contempt cases may have ended with Craig v. Hecht, 263 U. S. 255, 44 Sup. Ct. 103 (1923); but see infra note 50 .

"Blackstone's chapter "Of Misprisions and Contempts" (4 Conru. c. 9) deals with crimes which were never summarily punishable, and are no longer thought of as "contempts." BRACTON, DE LEGIBUS (13th century) $i$, 7 , indicates a much wider scope: "there is no greater crime than contempt and disobedience, for all persons within the realm ought to be obedient to the King and within his peace."

s The King v. Almon (1765), WILMOT, NOTES AND Opinions OF Jungnents (1802), 243, 255. "The Principle upon which Attachments are granted, in respect of Bailiffs, is to facilitate the execution of the Law. . . . But the Principle upon which Attachments issue for Libels upon Courts is of a more enlarged and important nature,-it is to keep a blaze of Glory around them." Ibid. at 270. 
tempt of it is not entirely extinct. Its power cannot be doubted by anyone who has taken the trouble to look beneath the sometimes transparent surface of a considerable number of cases of contempt by publication. But justification of the contempt power as a prerogative of majesty has become rather quaint than cogent. Moreover, in the days of monarchy by divine right, when injured majesty was a sufficient and respectable test of the crime of contempt, it was not a ground for dispensing with ordinary criminal procedure. Except in the Star Chamber, contempts were in general like other crimes, tried by jury, "according to the course of the common law."10

The exception of contempt from the ordinary requirements of due process of law was established not in antiquity, but in the period of dawning democracy and the rights of man, when it was incumbent upon courts to adduce for it a pragmatic sanction. ${ }^{11}$ This was done thus: "Laws without a competent authority to secure their administration from disobedience and contempt would be vain and nugatory. A power therefore in the supreme courts of justice to suppress such contempts, by an immediate attachment of the offender, results from the first principles of judicial establishments, and must be an inseparable attendant of every superior tribunal."12 We now, changing words only, say that the summary power is inherent, arising from the courts' necessity of self-preservation, or of preventing obstruction of their due administration of justice. ${ }^{13}$

${ }^{\circ}$ Collected in Nelles and King, Contempt by Publication (1928) 28 Coluarbra LAW Rev. 401 \& 525. Weldon v. State, 150 Ark. 407, 234 S. W. 466 (1921), is instructive as well as amusing. A judge before whom an indictment for bootlegging was pending, encountering the defendant at a bathing resort, spoke insultingly to him, and was insulted in return; the latter insult was held to be, not an "outdoor matter," but a contempt of court.

${ }^{10}$ Fox, op. cit. supra note $4,44-55$. It was early held that when the contempt was committed in facie curiae "the view supplied a conviction"; and confession, perhaps not always voluntary, often did so likewise. But even contempts in facie were often tried by jury. Ibid. at 227-242. The more enormous the contempt, the more reason for jury trial. "Richardson Ch. Just. de C. Banc al Assizes at Salisbury in Summer 1631 fuit assault per prisoner la condemne pur felony; que puis son condemnation ject un brickbat a le dit Justice, que narrowly mist; et pur ceo immediately fuit indictment drawn per Noy envers le prisoner et son dexter manus ampute $\&$ affix al gibbet, sur que luy mesme immediatement hange in presence de Court." Dyer (Eliz.) 188b, note. Only the amputation was upon the conviction by jury for the contempt; the hanging was for the antecedent felony.

11 "Who," said Lord Ellenborough in Carr v. Hood, 1 Camp. 350 n. (1808), "would have bought the works of Sir Robert Filmer after he had been refuted by Mr. Locke?" With the "refutation" of the doctrine of Divine Right the argument that the common law courts possessed the summary power as heirs of the Star Chamber (see Fox, op. cit. supra note 4,86 et seq.) became an anachronism.

${ }_{12} 4$ BL. Conm. 486.

${ }^{13}$ E.g., E.t parte Bollman, 4 Cranch 75, 94 (U. S. 1807) ; Cartwright's case, 114 Mass. 230 (1873) ; Carter v. Comm., 96 Va. 791, 32 S. E. 780 (1899); Bessette v. Conkey Co., supra note 6 . "The accumulated weight of repetition" behind this formula of the inlherent necessity" of the contempt power "is a constant invitation to think words instead of things." Frankfurter and Landis, Power of Congress over Procedure in Criminal Contempts in "Inferior" Federal Courts (1924) 37 HARv. L. REv. 1010, 1022-3. 
Though necessity is strait, it would be captious to insist that practicality may not construe it somewhat liberally. Loose claims of "necessity" may be made, however, to justify almost anything. "Not one of the oppressive prerogatives of which the crown has been successively stripped, in England, but was in its day defended on the plea of necessity."14 The word "necessary"- at least when it is not a constitution that we are construing ${ }^{15}$ - must reasonably mean more than "doubtfully desirable." It will here be used as meaning "highly expedient." It is "necessary" in this sense that the summary power should be ample. But its amplitude "is a command never to exert it where it is not necessary or proper."16 "Its great and only purpose is to secure judicial authority from obstruction in the performance of its duties."17 It does not extend to effecting justice; trial by jury is the procedure normally prescribed for that often unattainable object. "There is a difference between obstructing justice and obstructing the administration of justice. ... The administration of justice means the performance of acts and duties required by law in the discharge of duty."18 Though there is of course a penumbra as well as a distinction between justice and its administration, the mechanical rather than the substantive is the domain of the contempt power. It may be used whenever necessary for the due operation of the judicial machine-at least when there is no paramount expediency that it should not be. But necessity gives rise only to "the least possible power adequate to the end proposed."19 The power properly exists only when its exercise is necessary.

That such are the principles of the contempt power is copiously asserted and never denied. In particular cases, however, assertion of the necessity of the power in the abstract is often put to service as a substitute for demonstration of the necessity of its exercise in the circumstances before the court.

\section{The Varieties of Sumirarily Punishable Contempt and the ObJects of Punishment}

The phrase "varieties of summarily punishable contempt" does not here refer to the conventional classification of contempts as "civil" and "criminal." Few legal distinctions are emptier than that-except

14 1 Complete Works of Edward Livingston on Criminal Jurisprudence (ed. 1873) 264.

${ }^{15} \mathrm{Cf}$. M'Culloch v. Maryland, 4 Wheat. 316 (U. S. 1819).

${ }^{18}$ Gompers v. Bucks Stove \& Range Co., 221 U. S. 418, 451, 31 Sup. Ct. 492, 502 (1911).

${ }^{17}$ Ex parte Hudgings, 249 U. S. 378, 383, 39 Sup. Ct. 337, 339 (1919).

${ }_{18}$ Hough, J., in Rosner v. United States, 10 F. (2d) 675 (C. C. A. 2d, 1926).

${ }^{10}$ Anderson v. Dunn, 6 Wheat. 204, 227 (U. S. 1821). Cf. Brandeis, J., dissenting in Myers v. United States, 272 U. S. 52, 247, 47 Sup. Ct. 21, 66 (1926). 
of procedural technicality. The point to be made is that in summary proceedings, in the light of the principles of the power, the criminality of a serious contempt is almost completely irrelevant. The relevant questions are these: Is it possible in the particular instance to prevent, abate, or cure an obstruction of the administration of justice? If so, what is the least that will effect that end?

It may, however, be desirable to pause upon the conventional classification long enough to emphasize its misleading tendency. "Civil" contempt is defined as misconduct by which the rights or remedies of a party ... may be ... prejudiced." 20 The proceeding is on behalf of an injured litigant. The remedy is to require the contemnor to desist (usually from disobedience of an injunction, or interference with property impounded pendente lite), or to make good the complainant's damage from his violation of a duty imposed upon him by an order in a case in litigation. ${ }^{21}$ Subject to statutory limitations, the contemnor, if able to comply with the remedial requirement, may be committed until he does so. It is in effect a civil levy of execution which may include body execution. But I venture to say that every "civil" contempt whose contumacy is carried to the point at which the contemnor may be committed is a "criminal" contempt as well-and further, that the difference in form between summary proceedings in the interest of a private litigant and summary "criminal" proceedings in the public interest in correcting obstruction of the administration of justice has contributed to bring about substantial differences in object and result where there should logically be none.

In the Gompers case, ${ }^{22}$ for instance, the salient fact was that a judge summarily imposed severe criminal punishments (six to twelve months' imprisonment) for an act which the defendants honestly, and perhaps at that time not unreasonably, believed that they had a legal right to do. ${ }^{23}$ They had published that the Bucks Stove and Range

$\Rightarrow$ The statutory definition in New York and many other states; see Nelles and King, op. cit. supra note 9, at $421 \& 554$; Fox, supra note 4, at 44; Beale, Contempt of Cont, Civil and Criminal (1908) 21 HARv. L. REv. 161 ; Gomper's case, supra note 16.

"See cases cited in A Strike, etc., supra note 1, at 543-4.

- Supra note 16.

$\Rightarrow$ A man's honest mistake, ignorance, or inadvertance as to his legal duty does not, of course, relieve him from performance of it. But the normal procedure is not to punish him forthwith, but to admonish him to correct his dereliction. Only when his disregard of admonition makes his contumacy certain does it become necessary to resort to punitive coercion. Skip v. Harwood, 3 Atk. 564 (1747) ; cases cited in Oswald, stipra note 5, 102-3. The English usage is to order that an attachment for contempt "lie in the office," to issue only if the dereliction is not corrected. Disobedience of an order might well sometimes lead rather to its reconsideration than to punishment; in Levenstein v. E. I. Du Pont de Nemours Co., 258 Fed. 662 (D. Del., 1919) a defendant was punished for 
Company was "unfair" to organized labor in spite of an injunction forbidding them to do so. The necessity of enforcing the injunction (assuming its validity, that being a type of question which this paper avoids) surely did not require heavy penalties for its violation. The reversal, however, was not upon the ground that the clearly punitive sentences were not within the summary power. It was on the narrower ground that they were unauthorized because the proceeding was, in form, for a "civil" contempt. The defendants were thereafter resentenced in a new proceeding (prosecuted by the same counsel) in form for "criminal" contempt. ${ }^{24}$ This conviction was reversed upon the ground that prosecution had been outlawed by, or by the policy of, the criminal statute of limitations. ${ }^{25}$ Though the opinion of the court somewhat intimated that prosecution by indictment would be preferable to summary proceedings when the object is punitive, it did not hold that castigation in a timely summary proceeding for "criminal" contempt would be improper. It tended, therefore, on the whole to confirm the supposition that the criminality of contempts may be summarily dealt with.

refusing on advice of counsel to testify pursuant to a commission which was later held invalid. Ibid. 667 \& 991 (D. Mass. 1919).

Statements that contempt "does not depend upon the intention of the party, but upon the act which he has done" usually mean only that when the circumstances are such that no inference save that of his wilful contumacy is reasonably possible, no attention will be paid to the contemnor's quibbling as to the precise state of his mind and feelings; the much quoted language of Taney, $C$. $J_{\text {., }}$ in Wartman v. Wartman, 29 Fed. Cas. No. 17,210 (C. C. D. Md. 1853), should be -read in the light of the facts of the case. In corporation cases, if the ancient metaphysic be insisted upon, such circumstances as would prevent regard for a natural person's denial of confumacy will establish the contumacy of the artificial mind of the artificial being. Stancomb v. Trowbridge Urban District Counsel, L. R. (1910) 2 Ch. 190; Spokes v. Banbury Board of Health, L. R. 1 Eq. 42 (1865).

A non-contumacious obstruction of the administration of justice becomes contumacious upon the obstructor's disregard of an order to correct it. But until his contumacy has become actual, there can be no necessity for summary punitive measures. Ex parte Page, 17 Ves. Jr. 59 (1810). The West Virginia court which fined tardy counsel for delaying a trial in spite of the fact that their lateness was due to an automobile accident will scarcely be felt to have made a binding precedent. To pumish the persons who destroycd a subject matter in the belief that a decision of the Supreme Court had terminated litigation respecting it-a belief mistaken only in that the possibility of re-hearing was still open-would have been similarly outrageous. Merrimack River Savings Bank v. City of Clay Center, 219 U. S. 527, 31 Sup. Ct. 295 (1911). Cf. United States v. Shipp, infra note 58.

${ }_{24}$ The former severe sentences were re-imposed below. The intermediate appellate court, after citing authority for the principle that even in "criminal" contempt proceedings the object was but to secure present and future compliance with the injunction, not, as in "regular" criminal proceedings, punitive, reduced the sentences to one month in the case of Gompers and fines for his co-defendants. Yet the injunction, compliance with which was to be secured, had fallen with the settlement of the suit in which it had issued I In re Gompers, 40 App. D. C. $293,335-6$ (1913).

${ }_{25}$ Gompers v. United States, 233 U. S. 604, 34 Sup. Ct. 693 (1914). 
It is true both logically and historically that criminal contempt is a crime of the same general nature and punishable with the same objects as other crimes. As such a crime it is, both logically and historically, prosecutable by ordinary criminal procedure. But the habit and necessity of looking to criminal codes for definitions of crimes so prosecutable has led to forgetfulness of the fact that many of these crimes are contempts. We tend to apply that word only to things dealt with summarily. And since contempts (1) are criminal and (2) are dealt with summarily, it has seemed to follow that the criminality of contempts may always be dealt with summarily. Yet this is rather rarely done in fact. Courts punish for contempt sparingly. Their main use of the power is an in terrorem use-preventive, not punitive; and on the rare occasions when something that looks like a moderate punishment is summarily imposed, the remedial or preventive aspect usually outweighs the punitive. And in the still rarer instances of clearly punitive summary sentences for serious contempts, the qualms of disinterested observers are strong evidence of the occurrence of an abnormality approaching enormity.

When the mind disabuses itself of the specious non sequitur that the criminality of contempts may be summarily dealt with because contempts are (1) criminal and (2) subjects of summary abatement, and recurs to the principles of the sunmary power for definition of its limits, such qualms turn out to be as well founded logically as they are in feeling. Edward Livingston made in 1824 a statement of the limits implicit in the principles and policy of the power whose clarity resists improvement:

"A recurrence to the great principle of self-defence will serve to show with some certainty to what extent this power is necessary or proper. Courts are, or ought to be, armed with every power necessary to defend themselves. Noise, interruptions, violence of every kind, must be repressed; obedience to all lawful orders must be enforced. Thus far the law of self-defence goes, but no further. Is the violence over-has the interruption ceased-is the intruder removed-has the order which was disobeyed been complied with?here the power of the incorporeal being [i.e., the court], as well as that of the individuals in the analagous cases, ceases, and the duty of the sovereign power begins. That alone must punish-that alone can define offences and fix the penalty for committing them. An infringement of the legal rights of a court of justice is an offence, and that government is radically defective which places the power to punish it in the hands of the offended party. Here, then, we find the limit of that necessity, which is so much insisted on and so little understood. There is a necessity that courts should have the power of removing interruptions to their proceedings, but there is none that they should have the power to punish those interruptions; the laws must do that, by the instrumentality of the courts, but in the form prescribed by law. 
"If the argument has been as clearly expressed as its force is felt, it must be convincing to show that courts ought to be empowered to remove all obstructions to their proceedings; that all such acts shotld be punished only by the due course of law; and that proper punishments, inflicted by the regular operation of law, will deter from these acts much more effectually than the irregular agency of the offended party, who sometimes, from delicacy, will abstain from enforcing the penaity of the law-sometimes, from the indulgence of passion, will exceed it."

Livingston's proposed Penal Code for Louisiana would have allowed no summary punishment whatsoever; even for petty disturbance in the court room the limit of summary power would have been to hold the offender long enough to turn him over for regular criminal prosecution. ${ }^{27}$ So drastic a limitation of the summary power by so strict a conception of the necessity which justifies it would, though logical, be undesirable. Petty offenders are apt to enjoy complete immunity unless they can be summarily punished. The efficiency of various non-judicial autocracies which have been found highly expedient-those, for instance, of the commander of an army, the master of a ship at sea, and the traffic policeman-requires various degrees of punitive discretion. Tempering strict necessity with practicality, it would seem that the following varieties of contempt may well be subject to some degree of summary punishment:

1. Misconduct by officers of court in their official transactions. The court, like the general of an army, must maintain discipline among subordinates. This is perhaps the oldest head of punitive summary power. Except with respect to attorneys, as to whose discipline there has grown up a distinct and satisfactory body of law and practice, its use is mainly in terrorem. It rarely encroaches upon the domain of ordinary criminal proceedings. It seems appropriate that an embezzling receiver should be committed until he makes good his defalcations, if he is able. But should his criminal punishment be imposed in a summary proceeding ?28 $^{28}$

2. Petty disturbances in or about the judicial precincts. An efficient in terrorem power to maintain order and decorum must have teeth. Peccadilloes too trifling to be worth the bother of sending to another court for prosecution should not for that reason be committed with impunity. As to such matters the court may appropriately resolve itself momentarily into a petty criminal court. But its punitive power, like that

${ }^{2}$ Lrvingston, supra note 14 , at 264-6. The quoted passage has been much abridged without indication of the omissions.

${ }_{27} 2$ ibid., 59-60; CODE, Book ii, tit. $v$, ch. xi, arts. 205-8.

2 This was done in Cartwright's case, supra note 13. 
of a justice of the peace, is a little power to deal with little things. ${ }^{29}$ The angry defeated litigant who threw an egg at Vice Chancellor Sir Richard Malins in 1877 was summarily committed and, after five months' imprisonment, deported. ${ }^{30}$ Should he not rather, like the felon who threw a brick-bat at Chief Justice Richardson in $1631{ }^{31}$ have been prosecuted by indictment? The dignity of Mr. Justice Field was tarnished by his handling of the court-room broil in which Terry drew a weapon. ${ }^{32}$ The offence was too big, and the pressure on the court's personal feelings too strong, for the summary punishment to be seemly.

3. Petty disobedience or resistance to process or orders, or interference with their execution. There should be no feeling that courts may safely be trifled with. In times when feudal habits of self-help were still strong, an extensive summary punitive power for interference with process servers was reasonably deemed desirable. ${ }^{33}$ Today the quality as crime of any serious forcible obstruction of orders or process would usually be felt as outweighing its quality as obstruction of the administration of justice-a fortiori when, as in cases where riotous outsiders to litigation interfered with the operation of railways by receivers, the conception of the offence as involving interference with the administration of justice is highy artificial. ${ }^{34}$ The question of summary punishment for violation of labor injunctions involves questions of policy, too large for this article. It may, however, be noted that feeling that violation of such injunctions should not be punished save on conviction by a jury seems to be gaining ground, ${ }^{35}$ in spite of a tendency in other fields towards expansion of injunctive enforcement of criminal law. ${ }^{30}$ Where the true questions are as to the substantive criminality of conduct-of criminal justice itself, not of obstruction of

$\approx$ The reversal of contempt convictions in Gridley $v$. United States, $44 \mathrm{~F}$. (2d) 716,742 et seq. (C. C. A. 6th, 1930), might adequately have rested upon the sole ground that the lower court had unduly magnified its petty contempt power. 185-6.

Fox, The Practice in Contempt of Court Cases (1922) 38 L. QUAR. REv.

3is Supra note 10:

ss In re Terry's Contempt, 13 Sawy. 440 (C. C. D. Cal. 1888), aff'd, 128 U. S. 289, 9 Sup. Ct. 77 (1888). See also Swisher, StEpHen J. FIELd (1930) 320-342.

${ }^{33}$ In 1598 a defendant and his relatives and retainers, resisting service of a chancery writ, compelled the process server, at dagger's point and with a mastiff dog, to "eate the labell of the writ. ... And after the said Henry Parramore sent for drinke for him, which he cawsed hin to drinke with cromes of bread in the same." Aberforthe v. Hall (40 Eliz.), 1 Sanders, CHancery Orders (1845) 76. Such instances explain the special summary severity of Chancery and the Star Chamber with respect to interference with process servers. See Fox, supra note 4, 108-110.

"Op. cit. supra note 1.

${ }^{35}$ Michaelson v. United States, 266 U. S. 42, 45 Sup. Ct. 18 (1924).

ss For example, under anti-trust, prohibition, criminal syndicalism, and, most recently, anti-libel statutes. State v. Guilford, 174 Minn. 457,219 N. W. 770 (1928). 
its administration-resort to the summary contempt power is anomalous and subversive of its nature and principles.

4. Serious obstructions of the administration of justice which happen not to be punishable under criminal statutes. In jurisdictions where all contempts are per se subject to prosecution by ordinary criminal procedure, this class would not exist. In other jurisdictions, the appearance of an instance should be the signal for enactment of a criminal statute embracing it. The extent to which the class can reasonably be deemed to exist in the Federal courts by reason of the inconvenience of resort to state criminal courts, or the slackness of state officials, is a troublesome question. The list of indictable Federal crimes $^{37}$ may not quite comprehend all serious obstructions of the Federal administration of justice. When Federal prisoners committed to the county jail at Chicago were suffered to go at large, there may have been enough doubt (a) whether the sheriff was indictable under the Federal Criminal Code and (b) whether state officials would efficiently have prosecuted him, to justify the imposition of severe summary punishment. $^{38}$ With respect to acts such as most contempts by publication, which courts occasionaly consider serious obstructions of the administration of justice when sensible laymen and legislatures do not, it seems obvious that statutory and constitutional immunities from summary punishment should not be annulled by judicial legislation. ${ }^{30}$

The four classes which have been described include, it is believed, all cases in which a definitely punitive use of the summary power may be exercised without arousing grave concern. In other cases the summary power should reasonably be conceived as exhausted when it has prevented or cured an obstruction of the administration of justice, and as having no other legitimate object. Of course there is an inevitable overlap between prevention and punishment. It may be said that the object of punitive castigation for petty contempts is preventive. So is the object of the punishment of crimes, including serious contempts, by ordinary criminal procedure. What is suggested is this: When the serious criminality of a contempt is apparent, the most efficient prevention of its recurrence should naturally be by ordinary criminal prosecution; when that is untrue in fact, the summary power does - disservice as an inadequate substitute for the correction of inadequacy. In the light of its principles and policy-having regard also to the constitutional requisites of jury trial and due process-the summary power with respect to contempts which are seriously criminal reasonably

Infra note 42.

${ }^{3}$ United States v. Hoffman, 13 F.(2d) 268 (N. D. Ill. 1925), aff'd, 13 F.(2d) 278 (C. C. A. 7th, 1926).

${ }^{\circ}$ See Nelles and King, op. cit. supra note 9. 
exists only when its exercise may prevent or correct the obstructive effect of the particular contempt in the particular pending administration of justice to which it has reference, and only to the extent necessary to that end. Criminal punishment for serious irreparable harn is for the ordinary criminal law.

What has been stated is substantially the theory of the limits of the summary power which a century ago prevailed generally in American legislation. The legislative movement, though it had an earlier beginning in Pennsylvania, gathered momentum soon after Livingston's publication. His influence upon the New York Revised Statutes of 1829 is obvious. $^{40}$ His work was one of the authorities relied upon by the draftsmen (James Buchanan and Daniel Webster) of the Federal contempt statute of 1831; and he himself as a member of the Senate doubtless promoted that virtually unopposed legislation. ${ }^{41}$ Both the Federal and the New York statutes, though in different language, virtually limited the summary power to misbehavior in the presence of the court, or so near thereto as to obstruct the administration of justice, and disobedience or resistance to lazeful process, orders, etc., and provided that prosecution for serious obstructions of the administration of justice should be by ordinary criminal procedure. ${ }^{42}$ "It cannot be necessary at this day," said the New York Revisers, "to urge any reason for substituting the trial by jury in all possible cases, instead of a trial by an offended tribunal."43 The New York and Federal statutes were the models of most subsequent state legislation $;^{44}$ and there is no evidence, unless the proliferation of statutory injunctive remedies for

${ }^{\infty}$ Ibid. at $420-2$.

Ibid. at $527-531$.

- The Federal statute includes "misbehavior of any of the officers of the said courts in their official transactions," as summarily punishable contempt; the New York statute omits it. The provisions defining and limiting the sumnary power are compared in parallel columns, ibid. at 528-9.

In the New York Revised Statutes of 1829 , the limitations of the summary power and the provisions for "regular" criminal proceedings for serious contempts were dissociated; see ibid. at 421 , note 109 . Similar arrangement of substantially the same provisions, some amplified, is still retained; N. Y. Junic. LAw, \$\$750-781 (summary contempt proceedings), 476-9 (attorneys); N. Y. PENAL LAw, \$\$370381 (corruption), 530 (coercion), 580 (conspiracy), 600 (contempt), 810-14 (forging, destroying, falsifying, suppressing evidence), 860 (intimidation), 1231 et seq. (jurors), 1620 et seq. (perjury), 1690 et seq. (escape and rescue), 1780 et seq. (interference with public justice), 2050 et seq. (tampering with records), 2440 et seq. (witnesses); and see also 1820 et seq.

The Federal Act of Mar. 2, 1831, c. 98; 4 Stat. 487, had two sections: §1 (now 28 U. S. C. A. \$ 385) limiting the summary power; \&2 (now 18 U. S. C. A. \$241) making it indictable to obstruct, or endeavour to obstruct, the due administration of justice "corruptly, or by threats or force." $\$ 2$ has been supplemented by $18 \mathrm{U}$. S. C. A. $\$ \S 231-251$. The detachment of $\$ 2$ and its amplifications in the Revised Statutes and subsequently has caused the supplementary relationship of the "criminal" provisions to $\$ 1$ to be largely forgotten.

${ }^{43}$ REVISERS' REPORTS (N. Y. 1828) vol. iv, pt. iii, eh. iii, tit. ii, art. 1, sec. 10.

«Nelles and King, op. cit. supra note 9, at 533-4, 536, n. 45, 534 et seq. 
crimes be deemed such, of any important change of legislative policy in any statute book.

The same theory that punishment for serious contempts should be upon conviction by jury has in general prevailed in England without legislative compulsion.45 The impropriety of allowing a proper exercise of summary power to have unnecessary punitive effect was strongly recognized in the famous case of Maria Annie Davies. ${ }^{40}$ Mrs. Davies, defeated in 1877 in litigation in which she claimed title to property, declined to accept the judgment as concluding her rights. For nine years thereafter she continued to assert tbem, sometimes by force, sometimes by abortive legal proceedings. Enjoined at length from further assertion, she disobeyed the injunction, and was committed until she should agree to obey. Her contempt was grossly criminal; the contumacy of Mr. Gompers in the Bucks Stove and Range Company case was trifling in comparison. Though after two years' imprisonment she was still obdurate, she was released-on the ground (per Mathew, J. and Mellish, L. J.) that the continuance of summary incarceration after it had assumed a punitive character was intolerable. The dissent of Coleridge, $C$. J., was on the ground that her imprisonment seemed still essential to the efficacy of the court's decree in favor of her adversary in litigation; he agreed that to punish her was improper.

In this country the attrition by state courts of statutory restrictions upon punitive use of the summary power has been considerable.47 And the break-down of the Federal statute seems complete, now that it has been declared that it

"conferred no power not already granted and imposed no linitations not already existing."

${ }^{4}$ See Gompers case, supra note 25, at 611-612. The influence of Livington's master, Bentham, was of course consciously felt in England; and Livingston's own work was there highly regarded; Sir Henry Summer Maine characterized him as "the first legal genius of modern times." HUNT, Life of EdwARD LivingSTON (1864) 135.

${ }^{4}$ L. R. 21 Q. B. D. 236 (1888).

${ }_{47}$ It has been closely analyzed only with respect to contempt by publication, 28 Columbia LAw Rev. 536-8, 542 et seq.

${ }_{4}$ Toledo Newspaper Co. v. United States, 247 U. S. 402, 418, 38 Sup. Ct. 560,564 (1918). For prior tendency towards attrition of the statute with respeet to contempt by publication, see 28 Columbia LAw REv. 532, 539. For the concurrent attrition with respect to tampering with jurors and witnesses, more excusable in view of the somewhat undue rigor of the intended statutory limitation with respect to such contempts, see the cases cited infra notes 54 and 55 . That the statutory intention was that the summary power (save as to misconduct of officers of court and disobedience or resistance to writs, orders, etc.) should extend only to obstructive acts committed in close topographical propinquity to a sitting court can scarcely be doubted. See citations supra note 42 . The draftsmen felt a need of subjecting the courts to a limitation more definite and unequivocal than the abstract principle that the power may not be used punitively. 
But since, notwithstanding numerous and striking deviations, usage still for the most part conforms with feeling, sometimes expressed, ${ }^{49}$ that definitely punitive use of the summary power is not within its illimitable "inherent" scope, it may not be futile to hope that the frequency of such use will diminish.

\section{Some Instances of Regard and Disregard for the Principles of the Power}

The proper object of the power as here conceived may be re-stated as to bring about specific performance of legal duties incident to litigation-duties mainly of judges, jurors, parties, and witnesses. The power may reach the person who seeks to prevent another's performance of duty as well as the person upon whom the duty directly lies. The ultimate concern, as in law generally, is for justice; but the power enforces directly not justice but its due administration. This distinction, however, though clarifying, is not water-tight. A juror's duty, for example, is not simply to decide, but to decide fairly; a witness's is to tell the truth. And insofar as the summary power can contribute to secure faithful as well as formal performance of legal duty, without disregard of limiting principles, it is clearly desirable that it do so, serving justice itself as well as its machinery.

\section{Perjury}

The proper limits of the power with respect to perjury, long obscured in a cloud of loose decisions, have latterly tended to become clear. It would be intolerable that witnesses should testify in fear of summary punishment if they should seem to testify falsely. That would indeed make the contempt power a "legal thumbscrew"; an honest witness would be in danger of committal until he should testify in a way which the court deemed truthful. s0 $^{50}$ But the power can undertake a little more than to compel witnesses to answer questions somehow. In an illuminating case, a witness who "blocked inquiry" by persistent and manifestly perjured evasion of disclosure as to a matter surely within his knowledge was committed for ten days. "At the end of that time," said Judge Learned Hand, "he may appear before the commissioner and see whether he can tell a story which is not so obviously a mere sham." 51 The court did not, however, conceive that it

${ }^{10}$ Supra note 24.

ts Ex parte Hudgings, supra note 17 , holding that the District Court had tho jurisdiction to commit a witness for falsely insisting that he had no recollection of ever having seen certain persons write; the witness was discharged on habeas corpus, his committal having been "without due process of law."

:1 United States v. Appel, 211 Fed. 495 (S. D. N. Y. 1913), approved in Ex parte Hudgings, supra note 17 , at 383. 
could undertake either to extort the truth, or to punish for falsehood.

It might be rash to say that no perjury which is not assimilable to recalcitrancy may properly be dealt with summarily. But in other adjudicated instances the "necessity" or paramount expediency of summary committal is not always apparent. It is true, as was said in one such case, that "there is no essential difference" between obstructing the administration of justice by perjured evidence and by tampering with a juror or witness. ${ }^{52}$ The assumption, however, that either tampering or perjury is ipso facto punishable summarily quite ignores the limits implicit in the principles of the power.

\section{Tampering zeith Jurors or Witnesses}

With respect to tampering, adjudication is still cloudy. On the face of most of the cases it would seem that the criminality of tampering was the reason it was summarily punishable. ${ }^{53}$

Tampering with jurors ranges all the way from bribery and intimidation to the sort of undue influence which, however prejudicial, cannot practically be eliminated. A degree of friendly or unfriendly feehing on the part of jurors-and judges also-towards litigants and counsel is inevitably incident to a trial, and often affects its result. Deliberate "flirtation" with the jury is a branch of the art of a trial lawyer; it becomes contempt only when it is maladroit. Though it would rarely be deemed contemptuous to satisfy a juror's desire for a cigarette in the corridor during recess, social overtures which pass the vague line between common courtesy and affirmative ingratiation may well call for reprimand or punishment. Punishment for such a thing, even after the trial is over, would be within the "petty offence" power which has been conceded on perhaps illogical grounds of practical convenience. Improprieties which are possibly, even though not certainly, prejudicial should not be committed with impunity.

When tampering amounts to a serious crime, if a summary punishment will prevent prevention of a juror's faithful specific performance of his duty-for instance, by removing an intimidatory or corrupting pressure before it has done harm ${ }^{54}$-its imposition is clearly within the

${ }^{52}$ In re Steiner, 195 Fed. 299, 303 (S. D. N. X. 1912).

${ }^{2}$ See, e.g., Kelly v. United States, 250 Fed. 947 (C. C. A. 9th, 1918) and cases there cited.

5 This ground was taken in $I n$ re Brule, 71 Fed. 943,946 (D. Nev. 1895). It was seemingly available in Savin, Petitioner, 131 U. S. 267, 9 Sup. Ct. 699 (1889) and Cuddy, Petitioner, 131 U. S. 280, 9 Sup. Ct. 703 (1889). Those cases, however, devoted their argument to the statutory question, then still important, of whether the place of the offense was topographically near enough to the sitting court. The concentration of attention upon the over-rigorousness, in some cases, of this attempted limitation of the contempt power may be responsible for inattention, in cases only superficially similar (infra note 55), to the limits inherent in the principles of the power. 
principles of the power. But if the obstruction of the administration of justice has become an accomplished and irreparable fact-as when a juror has been bribed-is there any theoretically admissible reason why the offence should not be remitted to "regular" criminal proceedings? Yet a number of cases sustain summary punishments for tampering with witnesses or jurors when no ground for proceeding summarily is either apparent from the facts or stated in the opinion. ${ }^{55}$ And the recent case of Sinclair $v$. United States ${ }^{56}$ seems calculated to give wings to their encroaching tendency.

In that case the obstruction of the administration of justice by undue surveillance of jurors empanelled to try Messrs. Sinclair and Fall for conspiracy to defraud the government of oil reserves was no longer preventable or correctible. It had been accomplished. A mistrial had been declared on Nov. 2, 192\%. The "summary" proceedings were instituted thereafter on Nov. 22. The "summary" trial lasted from Dec. 5, 1927 to Feb. 21, 1928. A record of eight hundred and seventy-eight printed pages was filed in the Supreme Court a year later. In that court the question mainly considered was whether the defendants were in fact guilty of criminally obstructing the administration of justice. The court could discover, it said, "no reason for emasculating the power of courts to protect themselves against this odious thing," assuming without discussion an identity of area of summary and regular proceedings for crimes against the administration of justice. ${ }^{57}$ It ignored - the defendants' counsel had discreetly omitted to raise the pointthe absence of any acknowledgable reason why the interest in securing "trial by capable juries in important cases" generally would not have been adequately served by a regular criminal prosecution. It is not easy to see how the interest in trial by jury is served by dispensing with juries in cases appropriate for them.

The Sinclair indictment was still of course technically "pending" after the mistrial. But can a candid mind believe that the summary punishment for tampering was in fact directed towards securing a due administration of justice in a re-trial of the indictment? It seems obvious that fear of failure of justice in jury trials either for the oil conspiracy or the tampering was an operative unacknowledged reason for the "summary" punishment for contempt. In that respect the

In re May, 1 Fed. 737 (E. D. Mich. 1880), McCaully v. United States; 25 App. D. C. 404 (1905); Keeney v. United States, 17 F.(2d) 976 (C. C. A. 7th, 1927). In these cases the harm was done before summary proceedings were instituted.

279 U. S. 749,49 Sup. Ct. 471 (1929).

${ }^{67}$ Ibid. at 765 . The facts, unless construed with artificial narrowness, constituted an offence of "corruptly endeavoring to influence or obstruct the due administration of justice," indictable under 18 U. S. C. A. \$241. 
Sinclair contempt case is not unique. Such a fear, however, would equally justify summary punishment for murder. ${ }^{58}$ In no case noted has it been openly avowed as a ground for proceeding summarily. In one case a district attorney argued that a summary conviction should be sustained because of doubt whether an influential defendant could be convicted by a jury. "This amounts," said Judge G. W. Anderson, "to urging usurpation of jurisdiction in order to achieve a conviction thought impossible under the forms of law provided by Congress." 50

ss And may indeed be felt to have done so. Ex parte Wail, 107 U. S. 265,2 Sup. Ct. 569 (1882) ; United States v. Shipp, (on demurrer) 203 U. S. 563,27 Sup. Ct. 165 (1906) ; (on the merits) 214 U. S. 386, 29 Sup. Ct. 637 (1909).

In the Shipg case a negro had been convicted of rape by a Tennessee court, and sentenced to death. A Federal District Judge having denied his application for habeas corpus, an appeal to the Supreme Court of the United States was allowed, staying execution of the death sentence which would otherwise have occurred on the day following. A mob, stimulated by publication of the action of the Supreme Court, lynched the negro in the evening of the day that the appeal was allowed. There had been attempts to lynch him before his conviction.

The county sheriff (for non-prevention doubtfully amounting to collusion) and several active lynchers were punished for contempt of the Supreme Court. The case is clear to the effect that contumacious purpose to defeat that court's jurisdiction of the negro was the essence of the contempt. Cf. note 23 , silpra. It would seem that a lynching motived solely by animus against the negro for his alleged crime would not have been contemptuous.

The active lynchers were surely guilty of a gross criminal contempt-an obstruction, by force, of the due administration of justice in the Supreme Court -clearly subject to "regular" criminal prosecution under what was originally $\S 2$ of the contempt statute of 1831 . See note 42 , supra. The completeness and irreparableness of the obstruction are obvious. If, in the view here taken, there was justification for the summary punishment (which was by the Supreme Court itself, as an exercise of original jurisdiction), it must be found in the practical certainty that it would have been as impossible to convict the lynchers of contempt by jury trial in a Federal court in Tennessee as to convict them of murder in a state court. The question of the desirability of law enforcement when it is intolerable to the community it is supposed to serve is in this instance complicated. For it may be said that the enforcement of Federal law, desired by the people of the United States generally, should not be subject to defeat by merely local passions. Yet the lynching itself was theoretically of no possible Federal interest. It was nevertheless so clearly likely to be the real object of punishment that the use of the summary power may excite as much concern as approval.

Concern is greater in the case of the sheriff (Shipp) than in the case of the actual active lynchers. For the Supreme Court divided five to three on the question of his contumacy. It seems clear that that question would better have been remitted to a jury.

${ }^{3}$ Coll v. United States, 8 F.(2d) 20, 22 (C. C. A. 1st, 1925). This is unique among recent cases in giving effect to the clear intention of the Federal statute that tampering, when it is geographically remote from a sitting court, should not be summarily dealt with. Silpra notes 42 and 48 . The facts disclose a better reason than the physical remoteness of Dr. Coll's activities for reversing his summary conviction. Dr. Coll had been indicted with others for conspiracy to violate the Prohibition Act, on testimony by an acknowledged bootlegger who was himself under indictment, given in return for a promise of immunity from the district attorney. Dr. Coll's alleged contempt was an interview with the bootlegger at his house, four miles from court. According to Dr. Coll's witnesses the bootlegger then admitted that he had testified falsely against Dr. Coll before the grand jury "in order to get himself free from his own criminal troubles." The prosecution introduced evidence- "very doubtful evidence" in Judge Anderson's opinion-that Dr. Coll obtained the bootlegger's retraction by intimidation and 


\section{Implications}

In a short view of summary punishments for serious crimes, satisfaction may be felt that a degree of retributive justice was somehow visited upon persons generally believed capable of defeating justice in a jury trial. But is not such "justice" closer to mob law than to due process of law? Unless we are to acknowledge that influential persons cannot be convicted by juries, and acquiesce in reversion to the sort of conditions which the Tudor autocracy developed the Chancery and the Star Chamber to control-the law of the land being impotent with respect to the "over-mighty subject"60_it is inappropriate to permit the contempt power to advance toward superseding the due administration of justice which it exists to protect. It results from that advance that when we look at the boundary of the contempt power, instead of finding a penumbra as wide only as the variations of careful judgment on questions of the necessity of summary procedure in doubtful cases, we find it scalloped with strong protrusions into a clearly alien area, so that it seems that a familiar maxim may have to be revised to read, cessante ratione, non obstante progressat lex.

It is notorious that justice increasingly fails of effectuation through due process of law in criminal cases. It is natural to ascribe much of the blame to the inefficiency of trial by jury. But that inefficiency is but one of many surface symptoms of the real cause-a condition of society in which the will that justice should fail is often more powerful than the will that justice should prevail. Since, in cases where the will that justice should win is insufficient, the administration of justice by straight foot-ball is ineffectual, law-abiding emotion tends to condone, and even approve, resort by justice to trick plays for an occasional score-as when a gangster, practically secure from prosecution for major crimes, is convicted for not paying taxes upon his nefarious income. Approval of summary punishments for grave criminality is similarly short-sighted. Efficient justice through juries depends upon an intense and general desire for it in society at large. So also, however, does efficient justice through courts sitting without juries. The traditional attachment to trial by jury is supported by abundant evi-

suggestions of benefits. Dr. Coll's own emissary brought the interview to the attention of the district attorney in connection with an application for discontinuance of the prosecution of the indictment against Dr. Coll. The response to this application was the information against Dr. Coll for contempt.

The substantial non-technical ground for reversing Dr. Coll's conviction for contempt was doubt whether he was in fact guilty of obstructing the administration of justice. Perhaps the real obstruction occurred when the bootlegger was induced to give evidence against him before the grand jury-and the effect of Dr. Coll's pressure on the bootlegger was to remove it. The question called loudly for jury trial.

es 1 Holdsworth, Hist. ENG. Law (3d ed. 1923) chs. v, vi. 
dence that the degree by which judges are more remote than juries from pressures of ordinary feeling is apt to result in injustice. ${ }^{01}$ A substitution in general of summary for "regular" criminal procedure-the logical implication of approval of encroachments through the contempt power-might be a jump from frying-pan to fire.

It may seem reactionary to press for limitation of judicial power by conventional principles at a time when the cry is for its relief from the clutter of "theology" and "ritual" which both obscures actual grounds of decision and impedes recognition of desirable grounds..$^{62}$ In that cry I somewhat join-with unqualified enthusiasm for the penetrating analysis of legal phenomena upon which it is premised. But, as the Sinclair case illustrates, alongside of questions of justice in particular cases is the question of judicial power, which, like all other power, is of an encroaching nature and needs checks. I cannot feel that it has so completely rid itself of restraint by principles that all principles may as well be scrapped as worthless. Some principles, including those of the contempt power, are still, though unevenly, efficacious.

\section{YALE LAW SCHOOL}

WALTER NeLLES

"Witness, for safety in the uncontroversial past, the Star Chamber, and the judicial views which Erskine persuaded juries to overrule. Dean Green, for all his condemnation of trial by jury, recognizes that juries did important service to legal science by declining to follow artificial rules of law in negligence cases. JUDGE AND JURY (1930) 122.

(1930).

Green, op. cit. sipra note 61. Jerone Frank, LAw aNd the Modern MnND 